Section 3:

Opportunities and Challenges 


\section{The Alliance's Reinforced Maritime Posture: Strengthening NATO's Deterrence and Defence at Sea}

Sarah Tarry and Kaspar Pajos ${ }^{1}$

\section{Introduction}

Strategic importance of the maritime domain

In an era of increased globalisation, states, societies and commercial entities find themselves profoundly dependent on overseas trade, as well as access to global markets, natural resources and communications networks. The world's oceans are increasingly busy maritime highways. Currently, more than four-fifths of the world's merchandise trade by volume is carried by sea. ${ }^{2}$ Furthermore, undersea cables lying on the seabed are used to transmit an estimated $97 \%$ of global communications. ${ }^{3}$ Such volumes highlight the strategic importance of being able to ensure unhindered access to the maritime environment. The re-emergence of great power competition makes this imperative even more relevant in the future. NATO and its allies recognise this challenge and, in recent years, the alliance has taken a number of important steps to reinforce its maritime posture in order to successfully deter potential adversaries and to ensure much-needed access to markets, resources and communications during peacetime, crisis or conflict.

\section{NATO's evolving role}

NATO was founded in 1949 as a collective defence organisation. Its navies played a critical role in signalling the alliance's capabilities and resolve

1 Sarah Tarry is the Director, Defence Policy and Capabilities, in the NATO International Staff/Defence Policy and Planning Division, and Kaspar Pajos is a Voluntary National Contribution from Estonia serving in the Defence Policy and Planning Division.

2 UNCTAD, Review of Maritime Transport 2020, 20.

3 Sunak, Undersea Cables, 5. 
against the Soviet Union during the Cold War, as major deployments and exercises were used to demonstrate NATO's collective maritime strength and solidarity. ${ }^{4}$ Following the collapse of the Soviet Union, NATO's focus changed and it became an external security provider, most notably undertaking crisis response operations in the Balkans, Afghanistan and Libya. It also undertook lower-intensity counterterrorism and counter-piracy operations in the Mediterranean Sea and Indian Ocean in cooperation with its partners. Following Russia's invasion of Ukraine and the illegal occupation of the Crimea, as well as the continuing international threat posed by terrorism, NATO placed a renewed emphasis on deterrence and collective defence, while, at the same time, remaining engaged in projecting stability in its neighbourhood through crisis management and cooperative security activities. ${ }^{5}$ This is the essence of NATO's $360^{\circ}$ approach to security today, which seeks to deter threats, and, if necessary, to defend against any adversary.

\section{Threats and challenges}

The current security environment presents NATO with a number of distinct threats and challenges. ${ }^{6}$ While instability and continuing crises across the Middle East and North Africa are fuelling terrorism, NATO's greatest challenge in the maritime domain is to effectively deter an encompassing Russian threat, which is manifested by the surge of Russian naval capabilities into the North Atlantic, the Baltic and the Mediterranean. Russia has also expanded its fleet in the Black Sea, and there is an increased likelihood that Syrian ports could become a Russian stronghold in the Mediterranean for an extended period of time. ${ }^{7}$ There has also been an increase in Russian submarine activity. ${ }^{8}$ Russia is modernising its sea-based deterrent forces, anti-ballistic missile systems and is developing high-end strategic capabili-

4 Hudson, "The Renaissance at Sea", 24.

5 This also includes the Defence and Related Security Capacity Building (DCB) Initiative that was launched at the Wales Summit in 2014. As part of this Initiative, NATO is implementing DCB packages for Georgia, Iraq, Jordan, Moldova and Tunisia and has also received a request for DCB support from Libya.

6 For a more detailed overview, see NATO, "London Declaration", paragraph 3.

7 Schroeder, NATO at Seventy: Filling NATO's Critical Defence-Capability Gaps, 18.

8 Alleslev, NATO Anti-submarine warfare: rebuilding capability, preparing for the future, 1. 
ties that could potentially disrupt or deny allied operations. ${ }^{9}$ It has reinvigorated its warship construction with modern frigates, corvettes and patrol boats armed with long-range anti-ship and land-attack cruise missiles and is testing electronic spectrum jamming and manipulation, GPS disruption and the ability to interfere with undersea cables and pipelines. ${ }^{10}$ Looking further east, the alliance is witnessing the rise of China as a great naval power, which is increasingly present in the Euro-Atlantic area. In recent years, Russia and China have conducted joint naval exercises both in the Mediterranean and in the Baltic. At the same time, China has increased its emphasis on maritime security as a means to defend its geostrategic interests, and the Chinese navy keeps expanding its capabilities for power projection along vital waterways. ${ }^{11}$

\section{Coherence and the $360^{\circ}$ approach}

The Alliance Maritime Strategy, agreed in 2011, states that "deterrence relies upon proven capability, demonstrations of readiness, and effective strategic communications". ${ }^{12}$ While some observers ${ }^{13}$ have argued that this Strategy, written three years prior to Russia's military intervention in Ukraine, needs updating, this key statement certainly remains relevant in light of the alliance's ongoing adaptation efforts. Since 2014, NATO, as part of its $360^{\circ}$ approach to security, has been implementing the biggest reinforcement of its collective defence since the end of the Cold War. In practical terms, this has meant that the alliance has undertaken efforts to strengthen its deterrence and defence posture and to bolster its readiness, responsiveness and ability to reinforce any ally in response to threats from any direction. One of the main challenges is to establish coherence in the alliance's overall posture so that it remains credible across all domains and geographic regions. Implementing NATO's $360^{\circ}$ approach requires multidomain integration, but also capable, flexible, rapidly deployable, interoperable and sustainable maritime forces ${ }^{14}$ that can perform low-end and

9 Olsen, "Introduction: The Quest for Maritime Supremacy", 3-7.

10 Bergeron and Blount, "VII. NATO's Maritime Domain", 92.

11 Gresh, "The new Great Game at sea".

12 NATO, "Alliance Maritime Strategy", paragraph 9.

13 For example, see Sundstrom, "An adequate NATO maritime posture: the missing element for deterring Russia” or Allport, "NATO needs a new Maritime Strategy for its Northern Flank".

14 NATO, "Alliance Maritime Strategy”, paragraph 18. 
high-end tasks in both littoral and blue waters, if necessary. The recent efforts to reinforce the alliance's maritime posture contribute to this requirement and are important for achieving coherence in the alliance's overall posture.

\section{The Alliance's Reinforced Maritime Posture}

Since the Wales Summit in 2014, NATO has set a renewed course for strengthening its maritime posture. At the Brussels Summit in 2018, this work was brought together under the heading of the alliance's Reinforced Maritime Posture. ${ }^{15}$ This constitutes a policy framework that sets out how the alliance could employ its naval forces more effectively. Today, its implementation is well under way and this has served to reinvigorate the alliance's core maritime abilities and warfighting function, which had been neglected during the "peace dividend" of the post-Cold War era. Its continuing implementation, coupled with the focus on high-end maritime capabilities addressed in the NATO Defence Planning Process (NDPP), will lead to an even more credible alliance maritime posture that will further strengthen deterrence and defence and also serve to improve the allies' collective maritime skills and readiness for all types of operations. In doing so, the Alliance's Reinforced Maritime Posture also serves to support the implementation of the Alliance's Maritime Strategy.

\section{The Alliance's naval forces}

\section{Standing Naval Forces}

NATO's Standing Naval Forces (SNF) are the core maritime capability of the alliance and a centrepiece of NATO's maritime posture. ${ }^{16}$ The SNF provide the alliance with a continuous naval presence and warfighting capability on the seas, as its two Standing NATO Maritime Groups and two Standing NATO Mine Countermeasure Groups persistently carry out their programme of patrols, scheduled exercises, manoeuvres and port visits. In recent years, NATO has made significant efforts to increase its responsiveness. As part of these efforts it has enhanced its rapid-reaction force-the

15 NATO, "Brussels Summit Declaration", paragraph 19.

16 NATO, "Warsaw Summit Communique", paragraph 48. 
NATO Response Force (NRF)—by increasing its readiness and size. In the maritime domain, these efforts have led to the enhancement of the SNF with additional capabilities and the integration of the SNF's four Maritime Groups into the NRF. As a result, the SNF are now also increasingly capable as a rapid response force that could also act as a first responder. For an alliance of 30 nations, demonstrating interoperability remains vital for maintaining credible deterrence and defence, and multinational participation in the SNF enhances this by offering a continuous way for allied platforms to operate as an integrated force. Nevertheless, the SNF's value goes beyond ensuring the alliance's responsiveness and interoperability, as they are also used as a cooperative security enabler by offering opportunities through training with partners and port visits.

\section{NATO Readiness Initiative}

In case of crisis or conflict, the SNF would need to be quickly supported by allied follow-on naval forces. Thus, the alliance must also demonstrate the readiness of its other forces in order to reduce the threat of miscalculation and to remove the pursuit of a short war or fait accompli from potential adversaries' calculus. In recent years, the alliance has taken steps to reinvigorate its culture of readiness. As part of these efforts, NATO leaders launched the NATO Readiness Initiative (NRI) during the Brussels Summit in $2018 .{ }^{17}$ In the maritime domain, its implementation will mean that 30 major naval combatants with enabling forces will be organised and trained as elements of larger combat formations and these will be persistently held in high readiness. As a result, the NRI will further enhance the alliance's rapid response capability, as these naval forces could be used for rapid military crisis intervention or for reinforcement of allies in support of deterrence or defence.

\section{Coordination with allied naval forces under national command}

In addition to contributions to the SNF, the NRI and NATO exercises and operations, the allies have substantial naval forces under national command. These are also valuable assets and their availability is supported by the NDPP, which defines the pool of forces that could be made available

17 NATO, “Brussels Summit Declaration”, paragraph 14. 
to NATO. After all, the SNF only represent a small, spearhead element of the alliance's collective naval strength, and NATO's true maritime power lies in the SNF's ability to rapidly join high-capability national task groups with high readiness. ${ }^{18}$ Such coordination between the SNF and national units or task groups can be used to amplify the delivery of desired strategic effects, which, in turn, can lead to a stronger and more coordinated deterrence posture. In this way, even when the majority of allied naval forces remain under national command, they still make an important contribution to maintaining a unified alliance maritime presence. Leveraging this ability is a priority for the Allied Maritime Command (MARCOM) that, in recent years, has extensively focused on strengthening its linkages to other allied as well as partner maritime stakeholders. As part of these efforts, a new framework has been developed that encourages and facilitates timely information exchange, and will allow MARCOM to be both a hub and a portal for tracking events at sea and for consultations on how to respond. ${ }^{19}$ Having such a network in place in peacetime will allow MARCOM to fulfil its role in crisis and conflict better and, in this way, strengthen NATO's deterrence and defence posture.

\section{Standing integrated command structure}

\section{NATO Command Structure Adaptation}

Throughout its history, one of NATO's great strengths has been its standing integrated command structure, often considered the military backbone of the alliance. Over the years, the NATO Command Structure (NCS) has undergone a great deal of reorganisation to keep it fit for purpose and capable of providing command and control in all contingencies. This was also the idea behind the latest NCS adaptation, which was endorsed by NATO leaders at the Brussels Summit in 2018. ${ }^{20}$ While previous post-Cold War adaptations had resulted in a substantial decrease in personnel, this trend was reversed in 2018 with the authorisation of more than 1,200 additional staff. This personnel increase has enabled NATO to strengthen its existing headquarters and to enhance its command and control at the stra-

18 MARCOM, "NATO Maritime Group Exercises with French Carrier Strike Group".

19 Bergeron and Blount, "VII. NATO’s Maritime Domain”, 101-102.

20 NATO, "Brussels Summit Declaration", paragraph 29. 
tegic and operational levels as well as across domains. The adapted NCS has also further strengthened the alliance's regional understanding through stronger linkages with the NATO Force Structure ${ }^{21}$ and national headquarters.

\section{Strengthening MARCOM's contribution}

As part of NCS adaptation, MARCOM has grown in numbers, and this has allowed it to take on an increasingly important role. Within MARCOM, several structural changes have been made to enable it to fulfil its new mandate as NATO's 360-degree Maritime Theatre Component Command overseeing the many maritime challenges which cover the full spectrum of missions. In addition to previously existing subordinate commands for submarine and maritime air forces, MARCOM has recently established a separate subordinate command for surface naval forces. MARCOM has also set up a newly established Theatre Maritime Operation Centre, which will facilitate the command and control function of the three subordinate commands and support MARCOM in its role as the Theatre Component Command. Establishing this operation centre is an important step for the alliance in moving towards more comprehensive $360^{\circ}$ maritime situational awareness, as it can be used to compile a recognised maritime picture that can be shared with allies' joint and maritime operation centres. ${ }^{22}$

21 NATO Force Structure (NFS) provides the alliance with rapidly deployable, mobile, sustainable and flexible multinational forces and their command and control capabilities. The NFS is composed of allied national and multinational forces and HQs placed at the alliance's disposal on a permanent or temporary basis under specific readiness criteria. These provide a pool of forces in order to allow for a high degree of flexibility to meet the requirements of conducting and sustaining operations. In the maritime domain, there are four deployable headquarters that are able to command and control assigned forces up to NATO Task Force level: Headquarters Commander Italian Maritime Forces; Headquarters Commander French Maritime Forces; Headquarters Commander Spanish Maritime Forces; and Headquarters Commander United Kingdom Maritime. In addition to these, through the Naval Striking and Support Forces, NATO is able to offer command and control up to NATO Expanded Task Force level.

22 MARCOM, "NATO Command Structure Adaptation: MARCOM activates Surface Command". 


\section{Strengthening regional command and control}

NCS adaptation has also resulted in NATO strengthening its regional command and control arrangements. To this end, a new Joint Force Command has been established in Norfolk, United States, in addition to the two existing ones in Brunssum, the Netherlands, and Naples, Italy. The establishment of JFC Norfolk was born out of allied assessment of a changing security environment in which the North Atlantic is again seen as a critical region. This new headquarters is co-located with the United States Second Fleet. Its primary responsibility is to protect the vital lines of communication between Europe and North America and to ensure that crucial routes for reinforcements and supplies from North America to Europe remain secure. It provides command and control arrangements, maintains situational awareness, conducts exercises and draws up operational plans covering vast geographic areas, from the United States East Coast, past the GIUK gap $^{23}$ and into the Arctic. ${ }^{24}$ It has recently declared its initial operational capability and is expected to reach full operational capability by the end of 2021. The establishment of this headquarters is of particular importance for the transatlantic alliance, as it is the first NATO headquarters dedicated to the Atlantic since 2003.

\section{Exercises and interoperability}

\section{NATO's enhanced exercises programme}

NATO's enhanced exercise programme is an important element of the Alliance's Reinforced Maritime Posture. In recent years, NATO has tailored its exercise programme to better support reinvigorating the alliance's collective maritime warfighting skills. As a result, NATO and its allies are now increasingly using maritime and joint exercises to develop and maintain their key warfighting abilities. Some areas of responsibility that are being increasingly incorporated into NATO and allied exercises include the protection of sea lines of communication and rapid reinforcement, carrier strike, amphibious forces, anti-submarine warfare capacity, integrated air

23 The GIUK gap refers to a strategically important naval chokepoint in the North Atlantic. Its name is an acronym for Greenland, Iceland and the United Kingdom, and gap refers to the open ocean between these three land masses.

24 NATO, "NATO's new Atlantic Command declared operational”. 
and missile defence, as well as countering cyber and hybrid threats. Developing and maintaining these key responsibilities are necessary to ensure that the alliance is able to not only engage in low-intensity maritime tasks, but also to defend itself against peer adversaries. At the same time, exercises also serve to strengthen deterrence by demonstrating the alliance's capabilities and readiness, thereby affecting the strategic calculus of potential adversaries.

\section{Bringing back NATO's anti-submarine warfare capacity}

Anti-submarine warfare exercises are a good example of NATO utilising exercises to develop its collective maritime warfighting skills and demonstrate the alliance's capabilities and readiness for strategic messaging. In recent years, there have been numerous studies highlighting the need to protect transatlantic sea lines of communication against the Russian submarine threat. ${ }^{25}$ To be able to counter it, the alliance is reinvigorating its antisubmarine warfare capacity through its enhanced exercise programme. This has resulted in anti-submarine warfare being exercised with greater regularity and on a greater scale. A recent example of this is NATO's annual anti-submarine exercise Dynamic Mongoose held in the North Atlantic. Its 2020 iteration featured submarines from five allied nations training together with surface ships from four allied nations. The exercise was also supported by allied maritime patrol aircraft and host nation support. ${ }^{26}$ Similar cooperation and integration take place regularly in the Mediterranean with the annual anti-submarine warfare exercise Dynamic Manta. Both exercises contribute to developing collective maritime skills, but also to fostering interoperability between allies.

\section{Utilising joint exercises for multi-domain integration}

But it is not only interoperability between naval forces that matters. With its recent strategic military concept for the deterrence and defence of the

25 For example, see Hicks et al., Undersea Warfare in Northern Europe; Nordenman, "Back to the Gap: The Re-Emerging Maritime Contest in the North Atlantic"; Allport, Fire and Ice: A New Maritime Strategy for NATO's Northern Flank; and Nordenman, The New Battle for the Atlantic: Emerging Naval Competition with Russia in the Far North.

26 NATO, "NATO maritime exercise Dynamic Mongoose ends in the High North". 
Euro-Atlantic area, NATO is increasingly focusing on multi-domain integration. After all, NATO operates jointly, and its navies can only succeed as part of a multi-domain effort. Surface, sub-surface and above-surface capabilities and forces must work together to support joint forces and help deliver joint results. In recent years, NATO and its allies have increasingly been using exercises to practise such multi-domain integration. The most prominent example was the exercise Trident Juncture 2018, which was conducted in Norway. NATO used this exercise to test its ability to rapidly reinforce an Ally, but also to test the interoperability of allied and partner air, land, maritime, special operations and amphibious forces needed for such an operation. Around 50,000 troops, 250 aircraft, 65 vessels and up to 10,000 vehicles took part, effectively making it NATO's biggest exercise in recent years. ${ }^{27}$ On a smaller scale, reinforcement and multi-domain integration are also regularly practised. The annual United States-led multinational joint exercise BALTOPS is a good example. Its 2019 edition featured around 8,600 troops from 18 different countries and involved maritime, air and ground forces with about 50 ships and submarines, as well as 40 aircraft. ${ }^{28}$ Several amphibious assaults were an important feature of this exercise, highlighting the alliance's efforts to rebuild this capability.

\section{Exploiting new technologies}

In addition to multi-domain integration, NATO and its allies are also increasingly looking for ways to exploit opportunities provided by new technologies. This has been declared a major priority for the alliance. ${ }^{29} \mathrm{~A}$ number of initiatives established by allies and NATO bodies, such as the Centre for Maritime Research and Experimentation (CMRE), are under way and cover a broad spectrum of maritime engagement. Allies are increasingly looking to utilise unmanned systems, and NATO can facilitate this by bringing coherence to national efforts and by acting as a network. In this context, in 2018, 13 allies launched the NATO Maritime Unmanned Systems (MUS) Initiative. ${ }^{30}$ It aims to utilise world-leading research to increase allied interoperability between conventional forces and unmanned

27 NATO, "Trident Juncture 2018 media resources".

28 NATO, "NATO navies test readiness in Baltic Sea".

29 NATO, "London Declaration", paragraph 6.

30 Since 2018, three allies and one partner country have further joined the initiative. For more information, see NATO, "Two Allies and one partner join the Maritime Unmanned Systems (MUS) Initiative”. 
drones, to establish new tactics that truly leverage these technologies and to develop secure digital communications for military drones across domains. Addressing these priorities could enable the use of unmanned systems on a greater scale across the alliance. The first steps towards this have already been taken. In 2019, seven allies together with the CMRE, academia and industry conducted the world's largest and most complex maritime unmanned systems exercise off the coast of Portugal. The results were impressive, with maritime unmanned systems augmenting conventional forces in many scenarios. ${ }^{31}$ The increasing use of such novel systems enhances several key capabilities, such as maritime situational awareness, mine-counter measures or anti-submarine warfare.

\section{Cooperation with partners}

While NATO remains an important actor in global maritime security, it is also continuously looking for ways to cooperate with partners. In recent decades, the alliance has placed significant emphasis on projecting stability, which in the maritime domain could be described as the fusion of its crisis management, cooperative security and maritime security tasks. ${ }^{32} \mathrm{In}$ teraction and cooperation with partners has been wide-ranging. The SNF, through its training with partners and port visits, has been an important tool, but NATO's cooperative security efforts go beyond this and also involve maritime headquarters. This was first seen in Operation Active Endeavour $^{33}$ in the Mediterranean. Over the years, this evolved into a network-based operation mainly focused on collecting and processing information from various sources, including partner Maritime Operation Centres and vessels. Similarly, information sharing and coordination with partners was also key to Operation Ocean Shield in the Indian Ocean, where many other actors were simultaneously deployed and a Shared Awareness and Deconfliction (SHADE) mechanism was developed to share informa-

31 Brasseur, Murray and Trevethan, "NATO's 'startup' charts a bold future in maritime unmanned systems".

32 Moon, NATO and the Future Role of Maritime Power, 9.

33 Operation Active Endeavour was one of eight initiatives launched in response to the 9/11 terrorist attacks against the United States in 2001. Under Operation Active Endeavour, NATO ships patrolled the Mediterranean and monitored shipping to help deter, defend, disrupt and protect against terrorist activity. 
tion and coordinate efforts. ${ }^{34}$ NATO has learned a lot from these valuable operational engagements and is now applying its lessons learned in Operation Sea Guardian, which has succeeded Operation Active Endeavour in the Mediterranean. NATO has also engaged with regional actors through SHADE MED ${ }^{35}$ and continues to look for ways to increase coordination and facilitate information exchange with partners to enhance the alliance's maritime situational awareness.

\section{Conclusion}

\section{NATO's naval renaissance}

Since 2014, NATO's renewed emphasis on deterrence and collective defence has been well reflected in the Alliance's Reinforced Maritime Posture. Many of the skills that had atrophied during the "peace dividend" of the post-Cold War era are once again being prioritised. In what could be considered a "naval renaissance", the alliance has focused on rebuilding its collective maritime warfighting skills, including by utilising maritime and joint exercises to develop its capabilities and foster interoperability. These collective efforts demonstrate to potential adversaries the alliance's capabilities, responsiveness, readiness and ability to reinforce all allies in support of deterrence or collective defence. Such a demonstration is important, as remerging great power competition is likely to make unhindered access to the maritime environment increasingly indispensable for allied security. In this context, sea power will remain a key instrument in the promotion and protection of allied political, economic and diplomatic interests. The alliance will likely continue to face an increasingly unpredictable security environment that continues to feature a resurgent Russia and the rise of China. Taking this into account, NATO should remain an essential maritime forum for allies to develop a common appraisal of the changing maritime environment and to balance naval requirements and resources between NATO and other missions, operations and activities. While NATO has developed a robust set of maritime tools to deal with distinct threats and challenges, the effectiveness of the Alliance's Reinforced Maritime

34 MARCOM, "Cooperative security in the maritime domain and MARCOM's vital role".

35 The Shared Awareness and De-Confliction mechanism in the Mediterranean. 
Posture will ultimately be dependent on the allies' continued commitment of assets and their use in the most effective way.

\section{Works Cited}

Alleslev, Leona, NATO Anti-submarine warfare: rebuilding capability, preparing for the future, Brussels: NATO Parliamentary Assembly, 2019. https://www.nato-pa.int/ view-file?filename=/sites/default/files/2019-10/REPORT 150 STC 19 E rev. 1 fin ANTI-SUBMARINE WARFARE.pdf.

Allied Maritime Command (MARCOM), "Cooperative security in the maritime domain and MARCOM's vital role", 7 December, 2015. https://mc.nato.int/med ia-centre/news/2015/cooperative-security-in-the-maritime-domain-and-marcomsvital-role.

Allied Maritime Command (MARCOM), "MARCOM activates Surface Command", 4 April, 2019. https://mc.nato.int/media-centre/news/2019/nato-marcom -activates-comsurfnato.

Allied Maritime Command (MARCOM), "NATO Maritime Group exercises with French Carrier Strike Group”, 23 January, 2015. https://mc.nato.int/media-centr e/news/2015/nato-maritime-group-exercises-with-french-carrier-strike-group.

Allport, Rowan, "NATO needs a new Maritime Strategy for its Northern Flank", UK Defence Journal, 12 February, 2018. https://ukdefencejournal.org.uk/nato-nee ds-new-maritime-strategy-northern-flank/.

Allport, Rowan, Fire and Ice: A New Maritime Strategy for NATO's Northern Flank, London: Human Security Centre, 2018. http://www.hscentre.org/wp-content/up loads/2018/11/Fire-and-Ice-A-New-Maritime-Strategy-for-NATOs-Northern-Flan k.pdf.

Bergeron, James Henry and Blount, Keith, "VII. NATO's Maritime Domain", Whitehall Papers, 95, No. 1 (2020), 91-103. https://www.tandfonline.com/doi/ful 1/10.1080/02681307.2019.1731215.

Brasseur, Michael, Murray, Rob and Trevethan, Sean, "NATO's 'startup' charts a bold future in maritime unmanned systems". Defense News, 20 April, 2020. https://www.defensenews.com/opinion/commentary/2020/04/20/natos-start-up-c harts-a-bold-future-in-maritime-unmanned-systems/.

Gresh, Geoffrey, "The new Great Game at sea". War on the Rocks. 8 December, 2020. https://warontherocks.com/2020/12/the-new-great-game-at-sea/?utm_sourc $\mathrm{e}=$ WOTR+Newsletter\&utm_campaign=db0907651b-EMAIL_CAMPAIGN_10_3 0_2018_11_23_COPY_01\&utm_medium $=$ email\&utm_term $=0 \_8375 \mathrm{be} 81 \mathrm{e} 9-\mathrm{d} \overline{\mathrm{b}} 0$ $907651 \bar{b}-83320687$.

Hicks, Kathleen, Metrick, Andrew, Sawyer, Lisa and Weinberger, Kathleen, Undersea Warfare in Northern Europe, Washington, DC: Centre for Strategic and International Studies, 2016. https://csis-website-prod.s3.amazonaws.com/s3fs-public/p ublication/160721_Hicks_UnderseaWarfare_Web.pdf. 
Hudson, Peter, “The Renaissance at Sea”, RUSI Journal 159, No. 3 (2014), 24-28. https://doi.org/10.1080/03071847.2014.927994.

Moon, Madelaine, NATO and the Future Role of Naval Power, Brussels: NATO Parliamentary Assembly, 2016. https://www.nato-pa.int/document/2016-162-dscfc-1 6-e-rev1-fin-nato-naval-power-moon-report.

Nordenman, Magnus, "Back to the Gap: The Re-Emerging Maritime Contest in the North Atlantic”, RUSI Journal, 162, No. 1 (2017): 24-30. https://doi.org/10.1080/ 03071847.2017.1301539.

Nordenman, Magnus, The New Battle for the Atlantic: Emerging Naval Competition with Russia in the Far North, Annapolis, MD: Naval Institute Press, 2019.

North Atlantic Treaty Organisation (NATO), "Alliance Maritime Strategy", 18 March, 2011. https://www.nato.int/cps/en/natohq/official_texts_75615.htm.

North Atlantic Treaty Organisation (NATO), "Brussels Summit Declaration”. Press Release 2018 (074) 11 July, 2018. https://www.nato.int/cps/en/natohq/official_te xts_156624.htm.

North Atlantic Treaty Organisation (NATO), “London Declaration”, Press Release 2019 (115), 4 December, 2019. https:/www.nato.int/cps/en/natohq/official_texts _171584.htm.

North Atlantic Treaty Organisation (NATO), "NATO maritime exercise Dynamic Mongoose ends in the High North”, 10 July, 2020. https:/www.nato.int/cps/en/ natohq/news_177202.htm?selectedLocale=en.

North Atlantic Treaty Organisation (NATO), "NATO navies test readiness in Baltic Sea”, 9 June, 2019. https://www.nato.int/cps/en/natohq/news_166717.htm.

North Atlantic Treaty Organisation (NATO), "NATO's new Atlantic Command declared operational”, 17 September, 2020. https://www.nato.int/cps/en/natohq/ne ws_178031.htm.

North Atlantic Treaty Organisation (NATO), “Trident Juncture 2018 media resources”, 25 October-7 November, 2018. https:/www.nato.int/cps/en/natohq/ne ws_158620.htm.

North Atlantic Treaty Organisation (NATO), "Warsaw Summit Communique", Press Release 2016 (100), 9 July, 2016. https:/www.nato.int/cps/en/natohq/offici al_texts_133169.htm.

North Atlantic Treaty Organisation (NATO), "Two Allies and one partner join the Maritime Unmanned Systems (MUS) Initiative”, 20 November, 2020. https://w ww.nato.int/cps/en/natohq/news_179602.htm.

Olsen, John Andreas, "Introduction: The Quest for Maritime Supremacy", Whitehall Papers, 87, No. 1 (2017), 3-7. https://doi.org/10.1080/02681307.2016.129101 7.

Schroeder, Wayne, NATO at Seventy: Filling NATO's Critical Defence-Capability Gaps, Washington, DC: Atlantic Council, 2019. https://www.atlanticcouncil.org /in-depth-research-reports/report/nato-at-seventy-filling-nato-s-critical-defense-ca pability-gaps/.

Sunak, Rishi, Undersea Cables, London: Policy Exchange, 2017. https://policyexchan ge.org.uk/wp-content/uploads/2017/11/Undersea-Cables.pdf. 
Sundstrom, Ian, "An adequate NATO maritime posture: the missing element for deterring Russia”, Centre for International Maritime Security, 30 March, 2017. http://cimsec.org/adequate-nato-maritime-posture-missing-element-deterring-rus sia/31686.

United Nations Conference on Trade and Development (UNCTAD), Review of Maritime Transport 2020, New York, NY: United Nations Publications, 2020. https:/unctad.org/system/files/official-document/rmt2020_en.pdf. 
